\title{
10. DEPOSITIONAL FEATURES OF ORGANIC-CARBON-RICH BLACK AND GREEN MUDSTONES AT DSDP SITES 386 AND 387, WESTERN NORTH ATLANTIC
}

\author{
I.N. McCave, School of Environmental Sciences, University of East Anglia, Norwich, England, U.K.
}

\begin{abstract}
Examination of downhole variation in per cent organic carbon, per cent thickness of black sediment, radiolarian sand (radiolarite layers) frequency, per cent thickness of calcareous mudstone, and graded unit frequency, suggests (1) major organic productivity control of blackness and carbon content, (2) local variation in CCD level, and (3) some turbidite deposition for Sites 386 and 387. Cycles in the mudstones suggest oxygenation/deoxygenation controlled by circulation and organic productivity and deposition of the cycles under conditions analogous to those under anoxic bottom waters.
\end{abstract}

\section{INTRODUCTION}

Leg 43 of the Deep Sea Drilling Project returned to the area where mid-Cretaceous black mudstones had first been drilled on Leg 11 at Sites 101 and 105. It is the purpose of this paper to set out and examine some of the first-order lithological features of these mudstones and to suggest the environmental conditions under which they originated.

At Site 386, we recovered 180 meters of core from the 240-meters-thick green and black mudstone unit. This material is very well preserved and is little disturbed by drilling. It lies directly on basalt and is dated as Albian to upper Cenomanian. It is overlain by pelagic red claystones. At Site 387 the unit is about 104 meters thick, of which 38 meters were recovered. Most of this material is extensively fractured by drilling; however, in the six most complete cores of this unit (32 to 37 ) recovery averages 63 per cent (see Chapter 7). The unit overlies lower Barremian and older chalk and marly chalk, part of the Neocomian limestone sequence. Overlying the unit is red to reddish brown mudstone, the top of which has been determined as upper Campanian. Palynomorph dates (Habib, this volume) for the black clays range from Aptian (Core 37 ) to Cenomanian (Cores 30 and 31).

A pronounced peak in organic carbon content occurs at the top of the black mudstones at Sites 386, 387, and 105 . Values greater than 10 per cent are reached, compared to less than 5 per cent in the rest of the unit (Kendrick et al., this volume; Boyce, 1972). Paleontological dating places all three sections in the upper $\mathrm{Ce}$ nomanian, so it appears probable that this peak is the same at the three sites and that cessation of black mudstone formation was synchronous in the late Cenomanian, at about 93 m.y. There is a recurrence of black mudstone at Site 387 in the lower Paleocene, where a few black/dark greenish gray cycles occur.

\section{MAJOR FEATURES AT SITE 386}

The excellent preservation and large number of cores at this site has allowed calculation and plotting of a number of variables against depth below the sea floor (Figure 1).

\section{Per Cent Organic Carbon}

The per cent organic carbon data are mainly from the carbon-carbonate determinations made by the DSDP shore lab, together with 12 values obtained on board Glomar Challenger by John Kendrick. It was thought initially that there was a pattern of high carbon values at the top and bottom of the unit. While the pronounced high values are still found at the top, values at the bottom do not appear to be much higher than in the middle of the section. However, the sampling here is not random, nor have channel samples been taken. Average values calculated by Kendrick for the top of the unit to 760 meters, 760 to 810 meters, 810 to 900 meters, and 900 meters to bottom are 3.0, $0.6,1.2$, and 1.7 per cent, respectively, confirming the high-low-high pattern.

\section{Per Cent Thickness of Black Mudstone}

The percentage of the thickness of each core colored black (N1), grayish black (N2), brownish black (5YR $2 / 1$ ), olive-black (5Y 2/1), or greenish black (5 GY $2 / 1$ or $5 \mathrm{G} 2 / 1$ ) is plotted (Figure 1 ). This reveals high values in the upper and lower parts of the section with low values in the middle, from Cores 46 to 54. It is worth noting that most of the unit is not black, and in the blackest parts (Cores 55 to 65 ) the average is about 50 per cent with peak values of about 70 per cent. These mudstones are not all black in the sense of black shales such as those in the Devonian of the eastern U.S.A. (Marcellus, Chattanooga, New Albany, etc.) for example. 


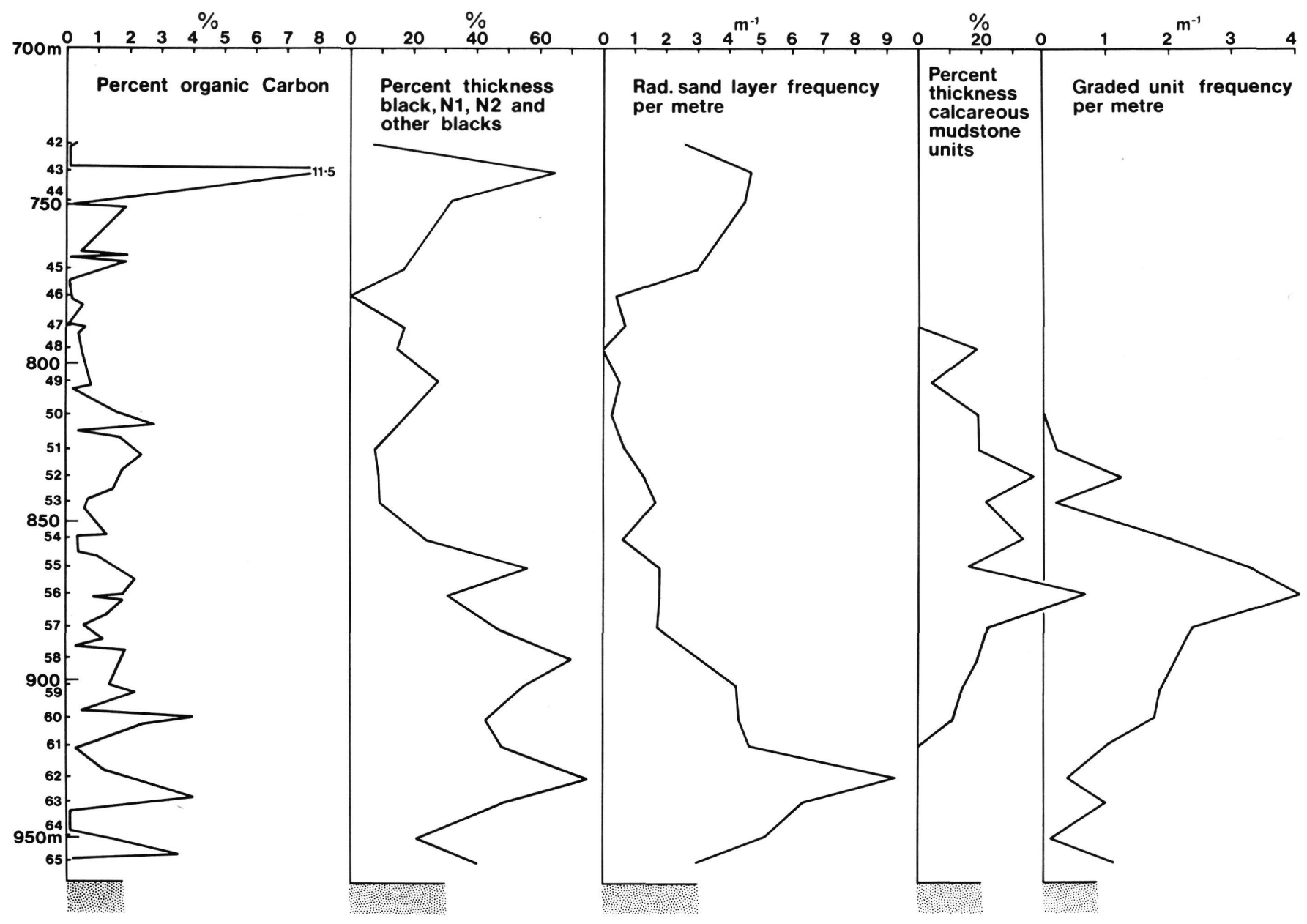

Figure 1. Downhole variation in parameters of the sediments in the green and black mudstones (Unit 7) at Site 386. Depth sub-bottom $(m)$ and core numbers (mid-point) are shown.

The initial impression of highs at the top and bottom of the section gained from carbon analyses is supported here. However the high blackness but lower carbon in Cores 55 to $59(860-900 \mathrm{~m})$ suggests that blackness is not due to carbon content. Most of the blackness probably results from the presence of finely disseminated pyrite. Many of the smear slides from black layers contain $>5$ per cent pyrite (see site report smear-slide diagram). Pyrite formation may well have been related to oxygen consumption in the oxidation of organic matter, and if most of the organic matter were consumed the resulting sediment would be black, but contain little organic matter. Blackness would not necessarily be accompanied by abundant organic material unless an excess was originally present.

\section{Radiolarian Sand Layer Frequency}

One of the intriguing finds at this site was thin radiolarian sand or silt layers (radiolarites), composed of a framework of mainly recrystallized radiolarians with a mud matrix. Many are hard and are fine sandstones. They are mainly 0.5 to $3 \mathrm{~cm}$ in thickness and are exceptionally up to 5 or $7 \mathrm{~cm}$ thick. They are mostly parallel to bedding. A few are burrowed down into under- lying mud, a few are laminated, but most are homogeneous. Grading is not apparent, and while most layers have sharp contacts, both the upper and lower contacts of some are gradational. Radiolarians are scarce in the interbedded mudstones, a pattern distinctly different from that at Site 387 only 180 miles to the west-northwest, where the green and black sediments are rad mudstones with far fewer radiolarite layers. Nevertheless, radiolarites are a feature of the sediments at both sites.

Hypotheses accounting for the occurrence of these layers may be divided into episodic input or episodic preservation. The first suggestion for episodic input was that the layers represent the products of a radiolarian productivity bloom. However the thickness of the layers seems to be too great for them to represent annual blooms. Calvert (1964) records the annual laminae in the Gulf of California diatomaceous sediments as $\sim 2 \mathrm{~mm}$. However most of the other features of the layers are compatible with the bloom explanation.

Another episodic mode of input is by turbidity current or a sand flow (Shepard, 1963, p. 320). In this it is suggested that radiolarians accumulated on the highs 
adjacent to the valley in which the site is located. Here they were winnowed free of mud and occasionally flowed down into the basin. While this disposes of the thickness problem, the lack of grading in the radiolarites does not support a turbidity current process. Furthermore, there are in the lower part of the section many small graded mud units thought to be turbidites (see below) but none above Core 50 . It would be most strange to have abundant radiolarian turbidites flowing into the trough but no other types in spite of the dominance of mud in the succession. Also, there are a number of these radiolarite layers at Site 387, not nearly as abundant, but present nevertheless. That site is not in an obvious depression and a nearby source from topographic highs would not have been available. So a turbidite or sand flow mechanism seems unlikely.

It is noted that the sediments at Site 386 are mudstones whereas those at Site 387 are radiolarian mudstones. This suggests a local environment at Site 386 with strong dissolution of silica, possibly because of its location in a depression. The episodic preservation argument is that from time to time an additional source of silica (volcanic ash?) was injected, thereby stopping dissolution of radiolarian tests in bottom sediments for a few years. There would be episodic preservation of a continuing high rate of radiolarian input. The difficulties with this hypothesis are firstly the similar trend shown by radiolarian sand frequency, blackness, and carbon content, the latter features being presumably unrelated to external silica input, and secondly the lack of independent evidence of volcanic ash in the succession.

A suggestion (by Brian Funnell) which gets around these problems is that the location of Site 386 was sufficiently equatorial $\left(\sim 20^{\circ} \mathrm{N}\right)$ not to have pronounced seasonal productivity patterns. So a "bloom" may have had a duration of tens or hundreds of years and have formed part of a larger scale productivity cycle. Some element of the preservation hypothesis needs to be retained because it has been suggested that the depositional trough was a restricted environment of high silica dissolution. Thus in the "long bloom" there must have come a time when the rate of radiolarian input became greater than dissolution rate possibly because of local silica saturation. Then the radiolarites accumulated.

\section{Per Cent Thickness of Calcareous Mudstone}

The middle part of the section contains appreciable (up to $40 \%$ ) amounts of calcareous mudstone. This is partly mutually exclusive with the more carbon-rich/ blacker/radiolarian-sand-rich parts of the section. Some carbonate layers are found above and below Cores 48 and 60 but they are few and thin.

The paucity of carbonate in the lower and upper parts of the unit suggests deposition close to or below the carbonate compensation depth. However, as the lower part of the section directly overlies basement, the CCD would have to have been particularly high, shallower than 3500 meters. The CCD involved may thus have been local, confined to the fracture valley and raised by increased dissolution due to increased $\mathrm{CO}_{2}$ production from oxidation of organic matter during the early and late parts of the deposition of the unit. If this suggestion is correct, then the relationship between radiolarian sands (representing organic matter input) and calcareous mudstone is explained, while the continuing high blackness into low radiolarian sand zones (Cores 55 to 57) might indicate an intermediate condition where carbonate was no longer dissolved, but conditions were still sufficiently reducing to form pyrite.

\section{Graded Unit Frequency}

A number of homogeneous units with a thin basal zone of mud-clasts are present in the section, and these have been shown to be turbidites (McCave, this volume, fig. 10). They are mainly thin, most being less than $10 \mathrm{~cm}$ thick, though one of $50 \mathrm{~cm}$ was found. In the zone of highest frequency (Cores 54-58) these units comprise about 30 per cent of the section.

Some of these units are calcareous mudstone. Some more of the calcareous mudstone units are probably turbidites but have not been recognized as such. There seems to be some temporal relationship between the occurrence of these turbidites and calcareous mudstone. It may be that higher rates of accumulation above the fracture zone valley during peak carbonate input gave rise to the turbidites.

\section{CYCLES}

Most of the green and black mudstone unit at Site 387 display cycles of a black homogeneous/green mottled type. In contrast, only Core 44 at Site 386 displays such a cyclic arrangement. The thickness and number of cycles is given in Table 1. From this the surprising feature of an identical mean thickness for the cycles at Sites 386 and 387 is seen. It is surprising because the preliminary estimates of accumulation rate give Site 386 a mean rate three times that at Site 387 , whereas the cycles are of very similar character (Figure 2).

\section{Site 386}

The typical cycle here, as at Site 387 , consists of a greenish gray burrow mottled portion grading upwards to a black homogeneous to faintly laminated mudstone. The upward transition into black is gradual

TABLE 1

Cycle Thicknesses

\begin{tabular}{ccccc}
\hline Core & Sections & Number & Thickness (m) & $\begin{array}{c}\text { Cycle } \\
\text { Thickness (m) }\end{array}$ \\
\hline $\begin{array}{c}\text { Site } 386 \\
\quad 44\end{array}$ & $2-4$ & 20 & 4.5 & \\
$\begin{array}{l}\text { Site } 387 \\
32\end{array}$ & $1-3$ & 13 & 2.75 & 0.225 \\
32 & $4-6$ & 15 & 3.90 & 0.21 \\
33 & $1-2$ & 7 & 1.54 & 0.26 \\
35 & $2-3$ & 19 & 2.77 & 0.22 \\
35 & 4, CC & 9 & 3.08 & 0.34 \\
36 & $1-4$ & 15 & 5.07 & 0.34 \\
37 & 3, CC & 15 & 2.25 & 0.15 \\
Site 387 totals and means: 93 & 21.36 & 0.23 \\
\hline
\end{tabular}




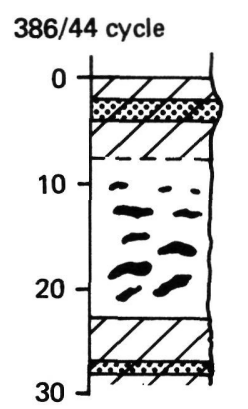

sharp or slightly gradational top.

rad sand

black (5YR 2/1). or N1.

gradation to

dk. grayish blue green (5BG 4/2)

to

light blue green (5BG 6/2)

with black burrow mottles.

black.

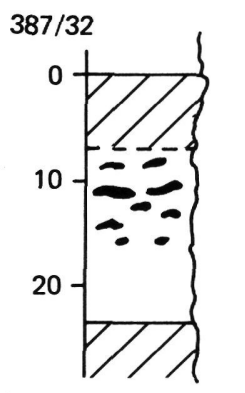

black

black mottles in homogeneous $\quad 5 \mathrm{G} 4 / 1$ to $5 \mathrm{GY} 4 / 1$

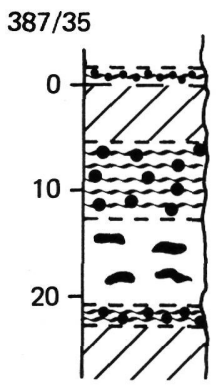

black N1-N2, 5YR 2/1

wavy lamination with small burrow mottles, dark gray (N3) with black mottles

greenish gray $(5 G 7 / 1)$ with large burrow mottles

\section{$387 / 36,37$}

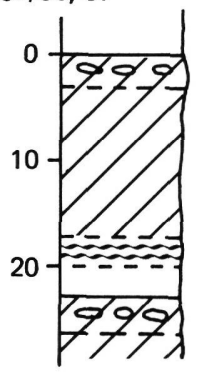

burrows on top of layer

black, homogeneous

wavy lamination, with mottles

greenish gray with black mottles

NOTE: rad sands are present in the cycles of cores 34 to 36 at Site 387 , but not always in the black layer.

Figure 2. Representative sections from cycles at Sites 386 and 387.

over 5 to $10 \mathrm{~cm}$ whereas the upward transition from black to greenish gray is rapid, occurring in less than 3 $\mathrm{cm}$ and in some cases the contact is quite sharp. In 15 of the 20 cycles in Core 44 the black part of the cycle contains a radiolarian sand layer. In contrast, only five of the greenish gray portions of cycles contain such layers.

In order to test whether there was any systematic set of grain size characteristics associated with these cycles, a number of samples were examined using the Coulter Counter method of McCave (this volume) (Figure 3).
From this it appears that there is no systematic set of characteristics; for example, the black mudstone at 68 $\mathrm{cm}$ has a coarse component whereas that at 82.5 does not. The blue-green at 62 and black at 68 are actually more similar. The principal point in common is that most samples have a modal peak at about $8 \mu$. There is no suggestion from these data that the units are turbidites. At Site 138 in the Canary Basin, Cenomanian cy-

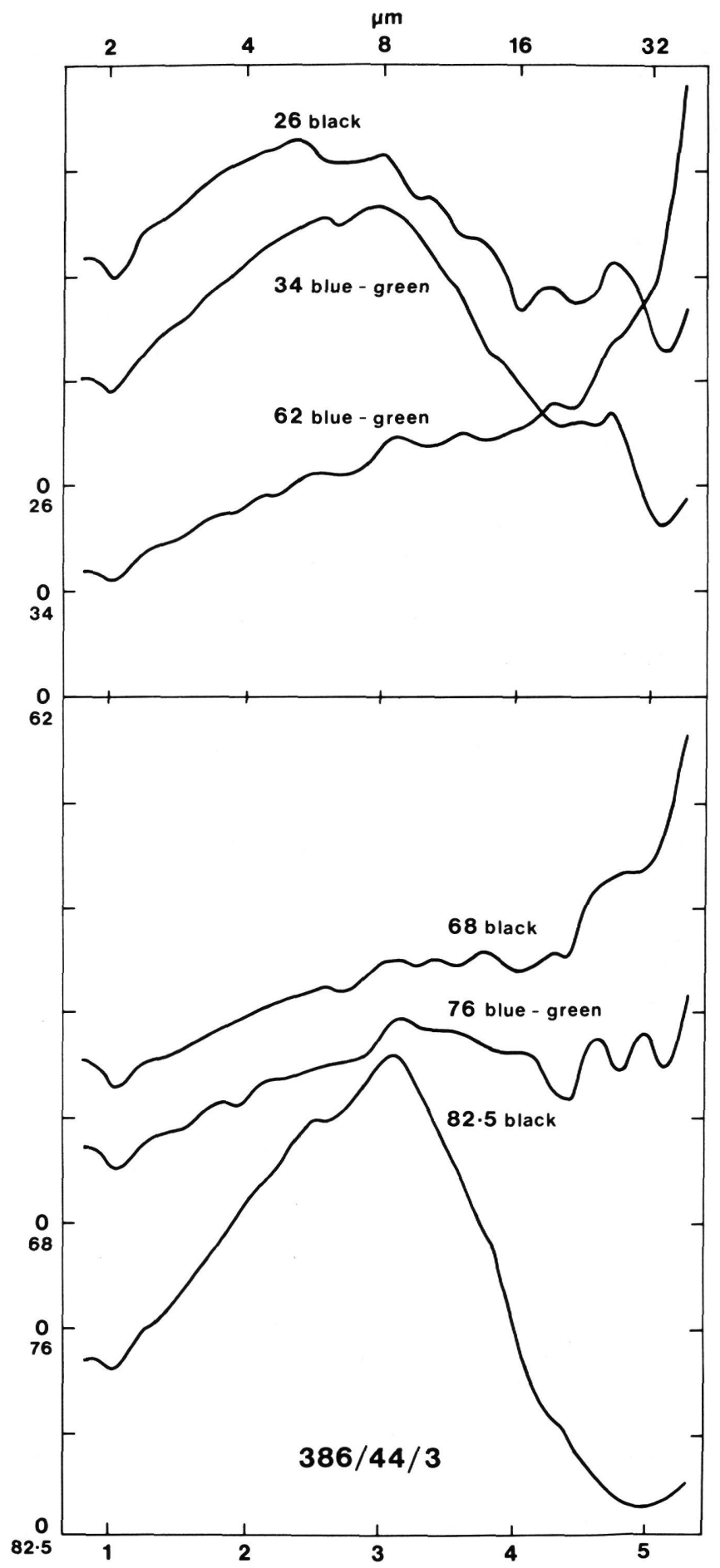

Figure 3. Grain-size spectra in the silt $(2-40 \mu \mathrm{m})$ range for samples from cycles at Site 386. 
cles of dolomite and sapropelite have been interpreted as dolomite turbidites emplaced in a sapropelite environment (Berger and von Rad, 1972). This type of hypothesis is not applicable here.

\section{Site 387}

Variants on the basic theme found at Site 386 occur in the cycles of Site 387. Three of these types are illustrated in Figure 2. Core 32 contains simple homogeneous (burrow mottled) greenish gray-black mottles in greenish gray-black mudstone sequence. Core 35 has the most complex cycle with large black burrow mottles passing up to smaller mottles in wavy lamination and then to black mudstone. Cores 36 and 37 contain cycles with a thicker black portion containing a few burrows in the uppermost few centimeters of the unit. Presumably some animals living in the overlying greenish gray mud made an occasional food-gathering excursion into the black muds below. Radiolarian sands are present in Cores 34 to 36 and more are found in the blacker parts of the unit. For example, Core 34, Section 3 contains five radiolarian sands and is estimated to be 30 per cent black, whereas Core 34, Section 4 contains nine radiolarian sands and is estimated to be 50 per cent black. These are the peak values of radiolarian sand occurrence in this unit.

\section{Duration of Cycles}

Paleontological data from Site 386 indicate a mean rate of accumulation for the unit of $\sim 16.5 \mathrm{~m} / \mathrm{m}$.y. About half of the unit contains about one-third turbidites and calcareous mudstones, features not present in Core 44 where the cycles are found. Thus, a rough correction for these components suggests a mean rate in Core 44 of $\sim 13.3 \mathrm{~m} / \mathrm{m}$.y. This yields a mean cycle duration of 17,000 years.

At Site 387 the age control is much poorer, permissible mean rates within the spread of ages being 10.5 to $5.4 \mathrm{~m} / \mathrm{m}$.y. These give cycle durations of 22,000 to 43 ,000 years. The good preservation and depositional setting of Site 386 suggests that the sequence is relatively free of hiatuses. The thinner section and poor recovery and preservation at Site 387 makes judgement on continuity of sedimentation difficult. However the similarity of the cycles at the two sites makes it most likely that they have the same duration. A value closer to 17,000 years rather than 43,000 years, and some hiatus in the succession at Site 387 are probable. An order of magnitude figure for the cycles is 20,000 years.

\section{Discussion}

The distribution of color and burrow mottling suggests control of the cycles by oxygen availability in the sediments. From an originally oxygenated state where there was wavy lamination in green mud with abundant burrowing organisms there was a gradual change to lack of burrowers, increasing pyrite (and organic carbon in layers where the color is brownish black 5 YR 2/1) and laminated mud deposition. Such a set of changes might have been brought about by periodic enhancement of organic productivity combined with sluggish bottom water renewal. In this respect, the occurrence of radiolarian sands preferentially in the black layers at Site 386 favors an organic productivity control. The "long bloom"' hypothesis advanced above for the radiolarian sands essentially proposes a periodic productivity variation. This could be responsible for the major features of these cycles. The cycles are interpreted as representing oxygenation/progressive deoxygenation controlled by variations in productivity and circulation. No necessity for barred basin conditions is envisaged; it is simply required that consumption of $\left(\mathrm{O}_{2}\right.$ the in oxidation of settling organic carbon is greater than the supply in bottom waters. The asymmetry of the cycles-interpreted as slow "blackening" but rapid return to non-black (oxygenated) conditionssuggests that some change in bottom circulation may also have been involved in generation of these cycles. Only in the case of the cycles in Core 387-35 is there a distinct transition zone above the black layer. For the others a rapid change to oxygenated bottom waters is probable at the time of deposition of the base of a green layer.

Climatic control for these changes seems probable. The broad pattern of ocean paleotemperatures summarized by Fischer and Arthur (in press) is of a broad low in the Neocomian, a high peaking in the Albian succeeded by a low in the Cenomanian-Turonian and high in the Santonian-Campanian. It is suggested that in the warmer periods taxonomic diversity and possibly productivity is greater. At the same time the formation of bottom water, and thus the intensity of oceanic circulation, is decreased (Fischer and Arthur, in press). Superimposed on this large-scale pattern may be variations in circulation and productivity triggered at the 19,000 -year precession or 41,000 -year obliquity periodicities accounting for the cycles found in these sediments. It should be noted that the pronounced carbon peak in the late (?) Cenomanian does not fall in one of the warm and organically diverse periods noted by Fischer and Arthur; rather it is in the trough of a cool, taxonomically poor period.

The work of Kendrick (this volume) on iron partitioning suggests that the more organic-carbon-rich and sulfur-rich claystones may have been deposited from anoxic, sulfide-bearing bottom waters. Such conditions may occur in the bottom of basins (e.g., the Black Sea) or on the upper slope and shelf under oxygen minima and plankton bloom situations (e.g., Walvis Shelf). The paleodepths of the sites indicate the basin bottom model is applicable here.

At Sites 386, 387, and also 105 (Lancelot et al., 1972) a pronounced peak of organic carbon content $(>10 \%)$ is found at the top of the unit in the late Cenomanian ( 94 m.y.). The crustal ages for these sites at the time of deposition of this material, presumed to be synchronous, were 14, 37, and 51 m.y., respectively. Corresponding paleodepths, with allowance made for sediment accumulation by Berger's (1972) method are 3500,4500 , and 4900 meters. It can be seen that 1400 meter elevation difference separates these sites. Furthermore, mid Cretaceous black clays occur to the west 
over Middle Jurassic(?) basement at Site 391 (Benson, Sheridan, et al., 1976). As this was probably the deepest point in the basin, possibly 200 to 300 meters lower than Site 105, it shows that the anoxic conditions persisted in the deepest waters of the basin. So it is concluded that anoxic bottom-water conditions occurred over at least the deepest 2000 meters of the basin.

At the time of deposition of the lowermost black clays at Site 386, Sites 386, 387, and 105 were aged 0 , 23 and 37 m.y., respectively, wlth paleodepths of 2150 , 4000 , and 4500 meters. In this case there may have been temporary anoxic conditions in bottom waters at sites up to 2500 meters above the deepest part of the basin. At no time could the phenomenon be called an oxygen minimum as there was no deeper water of higher oxygen content in the basin.

\section{CONCLUSIONS}

Depositional features of the black and green mudstones at Sites 386 and 387 demonstrate an overall control through circulation and organic productivity. Higher values of organic carbon at the top and at the base of the sequence at Site 386 are matched by increases in blackness of the section and by radiolarian sand frequency. Calcareous mudstone deposition did not occur at the beginning of deposition of the unit, possibly owing to a locally elevated CCD caused by $\mathrm{CO}_{2}$ released by oxidation of organic matter. Oxygenation/deoxygenation cycles with a duration of the order of 20,000 years are thought to be responsible for green/black alternations in sediments at Site 387 and in one core at Site 386. No necessity for barred basin conditions is seen; the periodic anoxic conditions were produced by excess organic matter over supply of oxygen. Possibly associated with this were variations in the circulation intensity in the basin. The situation was not one of an oxygen minimum as there was no deeper water of higher oxygen content.

\section{ACKNOWLEDGMENTS}

Many thanks to John Kendrick, Brian Funnell, and Brian Tucholke for profitable discussions and useful information. The manuscript was reviewed by Brian Funnell.

\section{REFERENCES}

Benson, W. E., Sheridan, R. E., et al., 1976. Deep Sea Drilling Geotimes, v. 21, p. 23-26.

Berger, W. H., 1972. Deep sea carbonates: dissolution facies and age-depth constancy: Nature (London), v. 236, p. 392395.

Berger, W. H. and von Rad, U., 1972. Cretaceous and Cenozoic sediments from the Atlantic Ocean. In Mayes, D. E., Pimm, A. C., et al., Initial Reports of the Deep Sea Drilling Project, v. 14: Washington (U.S. Government Printing Office), p. 787-954.

Boyce, R. E., 1972. Carbon and carbonate analyses, Leg. 11. In Hollister, C. D., Ewing, J. I., et al., Initial Reports of the Deep Sea Drilling Project, v. 11: Washington (U.S. Government Printing Office), p. 1059-1071.

Calvert, S. E., 1964. Factors affecting distribution of laminated diatomaceous sediments in Gulf of California. In van Adel, Tj. H., and Shor, G. G., (Eds.), Marine geology of the Gulf of California: AAPG, Mem. 3, p. 311-330.

Fischer, A. G. and Arthur, M. A., in press. Secular variations in the pelagic realm. In Cook, H. E., and Enos, P., (Eds.), Basinal carbonate sediments: Soc. Econ. Pal. Min. Spec. Publ. ser.

Lancelot, Y., Hathaway, J. C., and Hollister, C. D., 1972. Lithology of sediments from the western North Atlantic, Leg 11, Deep Sea Drilling Project. In Hollister, C. D., Ewing, J. I., et al., Initial Reports of the Deep Sea Drilling Project, v. 11: Washington (U.S. Government Printing Office), p. 901-949.

Shepard, F. P., 1963. Submarine geology: New York, (Harper and Row), 2nd Ed. 